\title{
Job Satisfaction of Civil Engineers Working in Irrigation Sector Under Government of Nepal
}

\author{
Achala Paudel \\ Engineer, Ministry of Energy, \\ Water Resources and Irrigation, \\ Singhadurbar, Kathmandu
}

\author{
Santosh Kumar Shrestha \\ Lecturer, Dept of Civil Engineering, \\ Pulchowk Campus, \\ Tribhuvan University, Lalitpur, \\ Nepal
}

\author{
Dr. Madhav Prasad Koirala \\ Associate Professor, \\ School of Engineering, \\ Pokhara University
}

\begin{abstract}
Civil Engineers are the back bone of the infrastructural development and civil engineers working in government service has direct link with the development of nation. Todays, many government projects of Nepal are facing problems of time and cost overrun which somehow can relate with the engineers job satisfaction. This quantitative study aimed to determine the level of job satisfaction among the civil engineers working in irrigation sector under government service in Nepal. Data were collected primarily through structured questionnaire response from 210 civil engineers working under Department of Water Resource and Irrigation and adopted descriptive statistical analytical techniques to analyze the variables using SPSS and MS-Excel. Result of the study indicates that civil engineers working in irrigation sector under government service of Nepal were generally satisfied with their job and mostly they are unsatisfied with the pay system and promotion opportunities. Based on designation level, civil engineers working at Gazetted $2^{\text {nd }}$ class level were more satisfied than other Gazetted $3^{\text {rd }}$ class level and Non- Gazetted $1^{\text {st }}$ class level. Study also reveals that males were more satisfied than females and based on job location, office based job engineers were more satisfied than site based job engineers.
\end{abstract}

Key Words: Job Satisfaction, Civil Engineers, Irrigation Sector, Designation Level.

\section{INTRODUCTION}

Job satisfaction in general is the degree to which individuals enjoy their job. Broadly a person's job fulfils his dominant needs in consistent with his expectations and values. The feeling would be positive or negative depending upon whether need is satisfied or not.

According to , it is the state of feeling resulting from appraising one's job experiences while job satisfaction results from both how we think about our work (our cognition) and how we feel about our work (our effect). Job satisfaction of project personnel enhances their morale, leaving positive impact on project cost, quality and time of completion . Different people have different nature of attitude and employees involved in same projects may perceive their work assignment, pay system, promotion opportunities and working condition differently. Some may feel their relation with their workgroup supportive while some may not and some find their boss friendly and provide them opportunities to make their own decision about their job while some may not find their supervisor that's sort of friendly. So, some employee view their job positively while some other negatively. Positive feeling about their job makes man happy and satisfied and happy and satisfied employees are the asset of the organization. It has been a worldwide ongoing interest for both researchers and organizations

\section{NEED OF THIS RESEARCH}

For Government officials, satisfaction with their job have strong implication for upgrading the quality of government services and have direct impact on the quality of services given to the citizen.. Civil Engineers who are known as Irrigation engineers in DoWRI have to face various problems such as political pressure, lies, immorality, dishonesty, injustice, and local issues etc. that has also put lots of immense pressure on them which ultimately lead to anxiety and frustration among them. Dis-satisfaction leads to De-motivation to them. When they are De-motivated then, they become careless on their works such as negligence in supervision of works, negligence in time limit, negligence in quality of works etc. Such types of activities creates severe problem in completion of the project and which leads to cost overrun which ultimately affects whole growth of the nation. Most of the projects under this department fail to complete within time limits. So, it is necessary to find the condition of employee in time to time and try to motive their employee. This study help to find out the level of job satisfaction of civil engineers working under Government service in different post/ level.

\section{RESEARCH OBJECTIVES}

- To explore the level of job satisfaction among civil engineers working in Irrigation sector under Government of Nepal.

- $\quad$ To find the relationship between jobs related variables with the level of job satisfaction.

- To compare Job satisfaction and Job related variables based on gender i.e. (male vs. female), based on Job location i.e. (office based Vs. site based) and based on designation level i.e. (Non-Gazetted 1st class officer Vs. Gazetted 3rd class officer Vs Gazetted 2nd class officer). 


\section{LITERATURE REVIEW}

The term job satisfaction is first introduced by Hoppock. According to him, Job satisfaction is any combination of psychological, physiological and environmental circumstances that cause a person to feel that I am satisfied with my Job.. According to this approach although job satisfaction is under the influence of many external factors, it remains something internal that has to do with the way how the employee feels. That is, Job satisfaction presents a set factors that cause a feeling of satisfaction. Job satisfaction is the general expression of the employee's positive attitude built up towards their job as a result of diverse features, social status and experience gained from their job.

The theories of job satisfaction have two different perspectives: Content theories and Process theories. Content theories are more concerned with individual needs and individual goals. They basically deal with "what" motivates employees in an organization.

There are number of factors which effect job satisfaction. Newstorm and Davis have considered job satisfaction as a multidimensional. A wide assessment of the literature specifies that the factors conducive to job satisfaction are: pay, work, environment, coworkers . Recommends work, pay, promotion, Supervision and co- workers as a major determinants of job satisfaction

Research on 308 non-supervisory hospital nurses in Taiwan by on the level of job satisfaction of hospital nurses in Taiwan revealed that routinization had greatest impact on job satisfaction, followed by positive affectivity and job involvement. Relation between Job level and Job satisfaction by founds that job level increased, so did job satisfaction. Results on the level of job Satisfaction among teachers with particular reference to corporate higher secondary school in Nepal by shows that there was a significant relation between jobs related factors and the level of job satisfaction. Similarly research on the level of Job satisfaction among employee of Commercial bank in Nepal by shows that majority of employees are satisfied and very few employees are dissatisfied with their job and also found that out of various factors job security, pay, promotion potentials, relationship with co-workers and supervisors are top most influencing factors to job satisfaction from high to low magnitude respectively and males are more satisfied than females.Research on engineering fields by on the level of job satisfaction

\section{DATA ANALYSIS AND FINDINGS}

Quantitative data analysis was performed based on data collected from the questionnaires. For the analysis, Statistical Package for Social Science (SPSS) and MSExcel were used. In this analysis, both descriptive Statistics (frequencies, percentages, means, St. Deviation etc.) and inferential statistics (Pearson Correlation Coefficient) were conducted.

DEMOGRAPHICAL FINDINGS OF THE SAMPLE among civil engineers working in hydropower sector in consulting firms of Nepal showed that $67.96 \%$ respondents were satisfied with the job despite of their low rating on pay and promotion opportunities. Similarly research by on the level of job satisfaction among civil engineers working in Building Sector of Nepal found that the civil engineers working in building sector in Nepal were generally satisfied with their job and were unsatisfied with the pay system and promotional opportunities. Results on the study of Job Satisfaction and Motivational Level of Civil Engineers working in DRILP-AF project by shows that employees were highly satisfied and motivated. $73.26 \%$ engineers working in DRILP-AF project were found satisfied.

\section{METHODOLOGY}

This research attempts to find the level of job satisfaction and establish the relationship between job satisfaction and job related factors like nature of job itself, pay/salary, promotion opportunities, relation with workgroup, relations with supervisors and working conditions. This research is based on qualitative analysis (Questionnaire Survey) and population for this research was taken from the Department of Water resource and Irrigation. Due to limitation criteria of qualification which was minimum Bachelor Degree, Among 417 Non-gazetted officer only 142 officers and among 375 Gazetted $3^{\text {rd }}$ class officer only 130 officers have minimum Bachelor degree in Civil Engineering but in case of Gazetted $2^{\text {nd }}$ class officer, since there is minimum Bachelor degree qualification criteria to reach this level, so all officers are taken as eligible and hence total population for this research was 427 .

To test validity and reliability of questionnaire, pilot test of 50 response (Non-gazetted officer -7, Gazetted 3rd class officer-34 and Gazetted 2nd class officer -9) were conducted. After validation 427 questionnaire were distributed and among them two hundred and ten (210) questionnaire were returned, yielding a response rate of 49.1 percent. According to , for the reliability of the research result, a response rate of 30 percent is must which is achieved but less good rate to assume its validity perfectly. Further test of validity of no. of respondent in research was done by calculating sample size of the population with confidence level $95 \%, \mathrm{p}=0.5$, error $=0.05$, and population $(\mathrm{N})=427$, get value of 202.2 which is less than the no. of valid respondents.

\begin{tabular}{|l|c|c|}
\hline & Frequency & Percentage \\
\hline \multicolumn{3}{|c|}{ Gender } \\
\hline Male & 170 & 81.0 \\
\hline Female & 40 & 19.0 \\
\hline \multicolumn{3}{|c|}{ Age } \\
\hline 25 yrs. or less & 24 & 11.4 \\
\hline 26 to 35 & 117 & 55.7 \\
\hline 36 to 45 & 30 & 14.3 \\
\hline
\end{tabular}




\begin{tabular}{|c|c|c|}
\hline 46 to 55 & 32 & 15.2 \\
\hline over 55 & 7 & 3.3 \\
\hline \multicolumn{3}{|c|}{ Qualification } \\
\hline $\mathrm{BE}$ & 116 & 55.2 \\
\hline Master's degree & 92 & 43.8 \\
\hline Ph.D. degree & 2 & 1.0 \\
\hline \multicolumn{3}{|c|}{ Work Under } \\
\hline Federal Government & 150 & 71.4 \\
\hline State Government & 60 & 28.6 \\
\hline \multicolumn{3}{|c|}{ Current designation } \\
\hline $\begin{array}{l}\text { Non- Gazetted 1st class } \\
\text { officer }\end{array}$ & 59 & 28.1 \\
\hline $\begin{array}{l}\text { Gazetted 3rd class } \\
\text { officer }\end{array}$ & 86 & 41.0 \\
\hline $\begin{array}{l}\text { Gazetted 2nd class } \\
\text { officer }\end{array}$ & 65 & 31.0 \\
\hline \multicolumn{3}{|c|}{ Current Experience } \\
\hline 0 to 1 yrs & 25 & 11.9 \\
\hline 1 to 3 yrs & 40 & 19.0 \\
\hline 3 to $5 \mathrm{yrs}$ & 41 & 19.5 \\
\hline 5 to 10 yrs & 57 & 27.1 \\
\hline Over 10 years & 47 & 22.4 \\
\hline \multicolumn{3}{|c|}{ Total Experience } \\
\hline 0 to 1 yrs & 7 & 3.3 \\
\hline 1 to 3 yrs & 25 & 11.9 \\
\hline 3 to 5 yrs & 52 & 24.8 \\
\hline 5 to $10 \mathrm{yrs}$ & 59 & 28.1 \\
\hline Over 10 years & 67 & 31.9 \\
\hline \multicolumn{3}{|c|}{ Job Location } \\
\hline Office based & 113 & 53.8 \\
\hline Site based & 97 & 46.2 \\
\hline
\end{tabular}

\begin{tabular}{|l|c|c|}
\hline \multicolumn{3}{|c|}{ Marital Status } \\
\hline Married & 149 & 71.0 \\
\hline Unmarried & 61 & 29.0 \\
\hline \multicolumn{3}{|c|}{ Annual Income } \\
\hline$<=3$ lakhs & 48 & 22.9 \\
\hline$>3$ to 6 lakhs & 147 & 70.0 \\
\hline$>6$ to 9 lakhs & 5 & 2.4 \\
\hline$>9$ to 12 lakhs & 10 & 4.8 \\
\hline & 37 & 17.6 \\
\hline None & 14 & 6.7 \\
\hline One & 36 & 17.1 \\
\hline Two & 32 & 15.2 \\
\hline Three & 46 & 21.9 \\
\hline Four & 38 & 18.1 \\
\hline Five & 7 & 3.3 \\
\hline Six and above & & \\
\hline
\end{tabular}

The demographic finding of this research paper having sample size 210 shows that the majority of civil engineers working in irrigation sector are males compared to females. Overall the respondents $81.0 \%$ were males while $19.0 \%$ were females. Majority of the respondents were of age between 26 and 35 years and majority have done BR whereas least respondent have done Ph.D. Findings also shows that majority of civil engineers works under Federal government $(71.4 \%)$ than state government $(28.6 \%)$ and current yrs. of experience in current organization of 5 to 10 yrs. and have more than 10 yrs. of total experience. It is clear that civil engineers working in irrigation sector have more office based job then site based. Majority of respondents of the respondents are married and yearly income in the range of Rs. 3 lakhs to Rs. 6 lakhs per year. Majority of respondent have 4 no. of dependents.

FREQUENCY DISTRIBUTION OF JOB SATISFACTION AND JOB FACTORS

\begin{tabular}{|l|c|c|c|c|c|}
\hline Variables & Highly Dissatisfied & Dissatisfied & $\begin{array}{c}\text { Neither Satisfied } \\
\text { nor Dissatisfied }\end{array}$ & Satisfied & Highly Satisfied \\
\hline JS by SGRM & $7(3.3)$ & $42(20.0)$ & $88(41.9)$ & $69(32.9)$ & $4(1.9)$ \\
\hline JS by SJFM & $2(1.0)$ & $11(5.2)$ & $111(52.9)$ & $85(40.5)$ & $1(0.5)$ \\
\hline Job Itself & $3(1.4)$ & $32(15.2)$ & $75(35.7)$ & $96(45.7)$ & $4(1.9)$ \\
\hline Pay/Salary & $20(9.5)$ & $116(55.2)$ & $61(29.0)$ & $11(5.2)$ & $2(1.0)$ \\
\hline Promotion opportunities & $4(1.9)$ & $53(25.2)$ & $90(42.9)$ & $61(29.0)$ & $2(1.0)$ \\
\hline Work Group & $2(1.0)$ & $5(2.4)$ & $34(16.2)$ & $158(75.2)$ & $11(5.2)$ \\
\hline $\begin{array}{l}\text { Supervision/ Supervisors } \\
\text { (Bosses) }\end{array}$ & $3(1.4)$ & $28(13.3)$ & $59(28.1)$ & $115(54.8)$ & $5(2.4)$ \\
\hline Working Conditions & $4(1.9)$ & $40(19.0)$ & $67(31.9)$ & $96(45.7)$ & $3(1.4)$ \\
\hline
\end{tabular}

Note: Figures in the parentheses are the percentages. 
Above table shows frequency distribution of Job satisfaction and Job factors

Job satisfaction by summation of Global rating method shows that (7) 3.3\% and (42) $20 \%$ of the respondent were unsatisfied whereas (69) $32.9 \%$ and (4) $1.9 \%$ of respondent satisfied with their job. (88) $41.9 \%$ of respondent undecided with the statement .Here, majority of respondent couldn't decide whether they were satisfied or not and most of other satisfied with their job. From this research, it concludes that majority of respondents were satisfied with job nature (45.7\%), relation with workgroup (75.2\%), relation with supervisor or boss (54.8\%) and Working Condition (45.7\%) of the organization whereas unsatisfied with pay system (55.2\%) of their organization and majority of respondent undecided on the promotion opportunities(42.9\%) provided to them.

Measure of Level of Job satisfaction and its Variables

\begin{tabular}{|c|c|c|c|}
\hline Variables & Mean & Std. Deviation & Coeff. Of Variance \\
\hline JS-SGRM & 3.10 & 0.86 & 0.28 \\
\hline JS-SJFM & 3.28 & 0.64 & 0.20 \\
\hline Job Itself & 3.31 & 0.80 & 0.24 \\
\hline Pay/Salary & 2.33 & 0.76 & 0.33 \\
\hline Promotion Opportunities & 3.02 & 0.81 & 0.27 \\
\hline Work Group & 3.81 & 0.60 & 0.16 \\
\hline Supervision/Supervisors (Bosses) & 3.43 & 0.81 & 0.23 \\
\hline Working Condition & 3.26 & 0.85 & 0.26 \\
\hline
\end{tabular}

JS: Job Satisfaction, SGRM: Single Global Rating Method, SJFM: Summation Job Factor Method

From this research, Civil engineers working in irrigation sector under government service of Nepal have mean of 3.1 by Global rating and 3.28 by Summation of Job factors with variance of 0.28 and 0.20 respectively. From this it was found that they are somehow satisfied with their job. From the weighted mean of Job factors shows that, mostly they are satisfied with the relation with their work group (3.81) and Supervisors (3.43) and unsatisfied with the Pay system (2.33) and promotion opportunities (3.02) of the organization.

Comparison of Weighted means based on Gender, Designation level and Job location

\begin{tabular}{|l|c|c|c|c|c|c|c|}
\hline \multirow{2}{*}{ Variables } & \multicolumn{2}{|c|}{ Based on Gender } & \multicolumn{2}{c|}{ Based on Designation Level } & \multicolumn{2}{c|}{$\begin{array}{c}\text { Based on Job } \\
\text { location }\end{array}$} \\
\cline { 2 - 9 } & Male & Female & $\begin{array}{c}\text { Non-Gazetted } \\
\text { 1st class } \\
\text { officer }\end{array}$ & $\begin{array}{c}\text { Gazetted } \\
\text { 3rd class } \\
\text { officer }\end{array}$ & $\begin{array}{c}\text { Gazetted } \\
\text { 2nd class } \\
\text { officer }\end{array}$ & $\begin{array}{c}\text { Office } \\
\text { based }\end{array}$ & $\begin{array}{c}\text { Site } \\
\text { based }\end{array}$ \\
\hline JS by SGRM & 3.22 & 2.6 & 2.73 & 2.91 & 3.69 & 3.13 & 3.06 \\
\hline JS by SJFM & 3.3 & 3.2 & 3 & 3.23 & 3.6 & 3.37 & 3.18 \\
\hline Job Itself & 3.36 & 3.13 & 2.83 & 3.26 & 3.83 & 3.4 & 3.22 \\
\hline Pay/Salary & 2.36 & 2.18 & 2.15 & 2.28 & 2.55 & 2.35 & 2.31 \\
\hline Promotion Opportunities & 3.08 & 2.75 & 2.68 & 3 & 3.35 & 3.11 & 2.92 \\
\hline Work Group & 3.81 & 3.85 & 3.71 & 3.74 & 4 & 3.87 & 3.75 \\
\hline $\begin{array}{l}\text { Supervision/Supervisors } \\
\text { (Bosses) }\end{array}$ & 3.48 & 3.23 & 3.08 & 3.44 & 3.74 & 3.51 & 3.34 \\
\hline Working Condition & 3.27 & 3.2 & 2.93 & 3.19 & 3.65 & 3.43 & 3.05 \\
\hline $\mathrm{N}$ & 170 & 40 & 59 & 86 & 65 & 113 & 97 \\
\hline
\end{tabular}

JS: Job Satisfaction, SGRM: Single Global Rating Method, SJFM: Summation Job Factor Method

This section of analysis help to find out the weighted means of Job satisfaction based on gender, designation level and job location.

Here based on gender reveals that, males are satisfied with job nature, promotion opportunities of the organizations, relation with work group, supervision or boss and suitable working conditions or environment but unsatisfied with the pay system of the organization. But in case of females, they are unsatisfied with not only with pay system of the organization but also the promotion opportunities of the organization. In overall, males are more satisfied than females in all aspects except work group and females are more satisfied with their workgroup then males.

Based on Designation level indicates that, all levels are satisfied with the relations with the workgroup and supervisor or bosses. Non -gazetted $1^{\text {st }}$ class officers are unsatisfied with the nature of job, pay/salary provided by the organization, promotion opportunities and working conditions while gazetted $3^{\text {rd }}$ class and $2^{\text {nd }}$ class officers are unsatisfied with the pay system of the organizations. In 
overall, Gazetted $2^{\text {nd }}$ class officers are more satisfied than gazetted $3^{\text {rd }}$ class and non-gazetted $1^{\text {st }}$ class officers.

Based on job location shows that, both office based and site based officers are satisfied with all aspects except pay system of the organization and office based officers are more satisfied than site based officers.

\section{RELATIONS OF JOB SATISFACTION WITH THE VARIABLES}

\begin{tabular}{|c|l|r|r|r|r|r|r|r|}
\hline \multicolumn{2}{|c|}{} & $\begin{array}{c}\text { JS- } \\
\text { SGRM }\end{array}$ & \multicolumn{1}{c|}{$\begin{array}{c}\text { Job } \\
\text { Itself }\end{array}$} & Pay/Salary & $\begin{array}{c}\text { Promotion } \\
\text { Opportunities }\end{array}$ & $\begin{array}{c}\text { Work } \\
\text { Group }\end{array}$ & $\begin{array}{c}\text { Supervision/ } \\
\text { Supervisors (Bosses) }\end{array}$ & $\begin{array}{c}\text { Working } \\
\text { Condition }\end{array}$ \\
\hline \multirow{3}{*}{$\begin{array}{c}\text { JS- } \\
\text { SGRM }\end{array}$} & $\begin{array}{l}\text { Pearson } \\
\text { Correlation }\end{array}$ & 1 & $.601^{* *}$ & $.421^{* *}$ & $.493^{* *}$ & $.287^{* *}$ & $.465^{* *}$ & $.380^{* *}$ \\
\cline { 2 - 9 } & Sig. (2-tailed) & & 0 & 0 & 0 & 0 & 0 & 0 \\
\hline & $\mathrm{N}$ & 210 & 210 & 210 & 210 & 210 & 210 & 210 \\
\hline
\end{tabular}

*. Correlation is significant at the 0.05 level (2-tailed).

**. Correlation is significant at the 0.01 level (2-tailed).

This section provide the relationship between job satisfaction and its job factors which shows that all the factors (Job itself, Pay/Salary, Promotion Opportunities, Work group, Supervision / Supervisors and Working Conditions) have significant relation with Job satisfaction at the 0.01 level (2- tailed)

\section{CONCLUSION}

Majority of civil engineers working in irrigation sector under Government of Nepal were satisfied with their jobs. Study indicates that overall civil engineers working in irrigation sector are most satisfied with work group, followed by relation and supervision they received, nature of job and working environment. Pay and promotion opportunities are the major factor for dissatisfaction to majority of civil engineers. There was significant relationship between Job factors and Job satisfaction. Civil engineers working in Gazetted 2nd class level were found most satisfied, followed by those working in Gazetted 3rd class level and then least satisfaction was among those working in Non-gazetted 1st class level and a significant relationship exist between job itself, pay, promotion, relation with work group/ coworkers, supervision they receive and working condition with the job satisfaction of civil engineers working in irrigation sector under Government of Nepal.

\section{RECOMMENDATION}

Though payment system of government organization has standard pay system, but it is not sufficient to fulfill engineer's needs or it does not match with the payment system with international. Management of government organization should focus on need satisfaction of engineers/employees, help in their personal career development, motivation \& encouragement to adopt the use of new technology \& methods for efficient work performance, international exposure to improve work methods \& methodology, institutional learning \& memory should be provided and carrying out various periodical survey to obtain high satisfaction level and performance.

\section{REFERENCES}

[1] Basnet,A. (2015). Job Satisfaction and Motivational level of Civil engineers working in DRILP-AF Project. Kathmandu, Nepal: ACME Engineering College.

[2] Bhatta, A. K. (2017). A Study of Job satisfaction Among Civil Engineers working in Building Sector of Nepal. Lalitpur, Nepal: Pulchowk Campus.

[3] Bista, P. (2016). JOB SATISFACTION AMONG EMPLOYEES OF COMMERCIAL BANKS IN NEPAL. Proceedings of the AustraliaMiddle East Conference on Business and Social Sciences (pp. ISBN 978-0-9925622-3-6). Dubai: The Journal of Developing Areas, Tennessee State University, USA.

[4] Chu, C. I., Hus, H. M., Price, J. L., \& Lee, J. Y. (2003). Job Satisfaction of Hospital Nurses: An empirical test of casual model in Taiwan. International Nursing Review, Vol 50, Pp 176-182.

[5] Hoppock.R. (1935). Job Satisfaction. Harpere and Brothers, p.47.

[6] Kayastha, D. P., \& Kayastha, R. (2012). A Study of Job Satisfaction among Teachers, Higher Secondary School of Nepal. International Journal of Evaluation and Research in Education, Vol.1, No.1, pp 41-44.

[7] Locke, E. A. (1969). What is Job Satisfaction? Organisational Behaviour and Human Performance, Vol 4, pp309-414.

[8] Luthans,F. (2002). Oranisational Behavior. New York: MCGrawHill.

[9] Robbins, S. R., Water-Marsh, T., Cacioppe, R., \& Millet, B. (1994) Organisation Behaviour: Cocepts, Controversies and application. Sydney: Prentice Hall.

[10] Robie, C., \& Schmieder, R. (1998). The Relation Between Job Level and Job Satisfaction. Group \& Organization Management. Retrieved from https://www.researchgate.net/publication/258138158

[11] Saari, L. M., \& Judge, T. A. (2004). Employee Attitude \& Job Satisfaction. Human Resource Management, Vol.43, No.4, pp395407.

[12] Saunders, M., Lewis, P., \& Thornhill, A. (2009). Research Methods for Bussiness Students. Prentice Hall.

[13] Sharma Poudel, B.P. (2002). Employee Job Satisfaction in particular reference to engineering and architectural consulting firms of Nepal. Lalitpur: Nepal Engineering College.

[14] Subedi K.P, Chaudhari A.K. (2014). A study of Job Satisfaction status on civil service employees of Nepal. International Journal of Research and Scientific Innovation, Vol.I(No. V), Vol. I.

[15] Thapa.P. (2016). A Study of Job Satisfaction among civil engineers working in Hydropower Sector in Consulting Firms of Nepal. Lalitpur, Nepal: Pulchowk Campus. 